\title{
Os indígenas Xukuru do Ororubá e as formas de trabalho: de agricultores a operários e produtores orgânicos (Pesqueira e Poção/PE)
}

\author{
Edson Silva*
}

\section{Considerações iniciais: sobre o trabalho indígena}

O trabalho indígena compulsório ou não na História do Brasil ainda é por demais desconhecido e muito pouco estudado. Esse desconhecimento resulta das narrativas históricas enfatizando que a escravidáo negra substituiu, eliminou a escravidão indígena ocorrida apenas nos primeiros anos da colonização portuguesa. A importância do trabalho indígena foi evidenciada no livro pioneiro do historiador John Monteiro, ao escrever que os "negros da terra" (Monteiro, 1994), como eram nomeados os escravizados indígenas, foram fundamentais na história colonial de São Paulo (SP). Sem o trabalho escravizado indígena não haveria São Paulo! E nem tão pouco o sertanismo Bandeirante. Bem como as conexốes e relaçóes da escravidão indígena, a exemplo da necessidade de Pernambuco fornecer a força de trabalho escravizado indígena para a São Paulo colonial.

Na mesma perspectiva, Maria Regina Celestino de Almeida apontou a importância dos aldeamentos indígena no Rio de Janeiro (RJ) colonial (Almeida,

Professor Titular de História da Universidade Federal de Pernambuco (UFPE). Doutor em História Social pela Universidade Estadual de Campinas (UNICAMP). Professor no Centro de Educação/Colégio de Aplicação da UFPE; docente no Mestrado Profissional em Ensino de História (PROFHISTORIA) da UFPE e no Programa de Pós-Graduação em História na Universidade Federal de Campina Grande (UFCG).E-mail: edson.edsilva@hotmail.com. 
2013), como tropas militares, trabalho negligenciado nas análises históricas, para defesa contra índios considerados hostis pelos portugueses e também para proteger a colônia combatendo os franceses. Os índios aldeados também eram força de trabalho compulsória, às vezes recebendo remuneraçóes irrisórias, empregados na construção de fortalezas e em serviços públicos. Os indígenas construíram o Aqueduto da Carioca, trabalharam na abertura da estrada do Rio de Janeiro para Minas Gerais, nas pedreiras, em extração de madeiras das matas. E em muitas atividades nos serviços domésticos para particulares, recrutados como remeiros, guias, caçadores, nas expediçóes aos sertóes, para combater quilombolas; nas pastagens e lavouras, para a importante e necessária produção agrícola destinada a alimentação da colônia.

No Arquivo Público Estadual de Pernambuco, encontram-se vários documentos sobre a Aldeia da Escada, localizada na Zona da Mata Sul de Pernambuco, oficialmente declarada extinta por pressóes de senhores de engenho em 1861, com referências de indígenas trabalhando nas lavouras de cana-deaçúcar próximas ao aldeamento. Possivelmente foram empregados nas obras para construçáo da Estrada de Ferro Recife-Sáo Francisco, que cruza aquela região. Transferidos para Riacho do Mato (atual Município de Jaqueira-PE), trabalhavam na agricultura e no corte de madeiras, a maioria para a construção naval. Empregados em obras públicas, em milícias realizando diligências nas abundantes e densas matas existentes no local (Silva, 1995).

O importante trabalho de indígenas em tropas militares, em milícias legais ou particulares foi pouco considerado nas reflexóes históricas, embora muitas vezes decisivo na definição dos combates. Um estudo sobre as mobilizaçóes dos povos indígenas na Mata Sul pernambucana no século XIX, evidenciou a importância dessa participação de indígenas em tropas no chamado ciclo das revoltas liberais em Pernambuco (1817-1848). Os índios aldeados em Jacuípe (AL), Barreiros, Escada e Cimbres (PE) atuaram de forma significativa nas forças militares, em tropas legalistas ou como aliados dos revoltosos. Mesmo com recrutamentos compulsórios, foi analisada a participação indígena nos conflitos como forma de inserção na arena política, com os índios barganhando interesses, negociando com as oligarquias locais e considerando as relaçóes de poder provincial para conquista de benefícios pontuais e, sobretudo, o controle na administração dos aldeamentos e garantias das terras habitadas (Dantas, 2018).

Buscaremos neste texto evidenciar as diversas formas de trabalho dos indígenas Xukuru do Ororubá, atuais habitantes em um território nos municípios de Pesqueira e Poção, no Semiárido pernambucano, região com poucas chuvas anuais e longas estiagens ou secas prolongadas. A partir de relatos das memórias orais indígenas, apoiado nas reflexóes de Halbwachs e Verena Alberti (2004) sobre 
as memórias e de diálogos com autores que discorreram acerca daquela região, refletiremos sobre as diversas formas do trabalho indígena ressaltando, sobretudo, os protagonismos indígenas nos processos históricos.

\section{Agricultura e criação de gado: o trabalho indígena no período colonial}

A colonização portuguesa na região do atual Agreste/Semiárido pernambucano iniciou em meados do século XVII, depois de uma grande pressão demográfica no litoral impulsionando a colonização para o interior. Nas terras costeiras estavam os plantios da cana-de-açúcar, gramínea bastante suculenta, apreciada pelos bovinos, significando prejuízos nos lavouras. Multiplicaram-se os pedidos à Coroa Portuguesa de terras no "sertáo": senhores de engenho alegavam possuir gados sem terras para criá-los (Medeiros, 1993, p. 23-26). Foram concedidas sesmarias, legitimando-se assim a expansão colonial, com invasóes das terras indígenas.

Para a instalação das fazendas de gado era necessário amansar os índios "hostis". Em 1671, os missionários Oratorianos fundaram no "Ararobá" (Serra do Ararobá) ${ }^{1}$ uma aldeia de índios Xukuru. Os religiosos dedicaram-se ao comércio de gado, com aquisição de mais terras nas localidades próximas à Missão (Medeiros, 1993, p. 35-64). O local era considerado "a chave de todo aquele sertão"; razão pela qual foi mantida, por muito tempo, a Missão do Ararobá, como ponto de apoio para a expansão colonial portuguesa desde o atual Semiárido pernambucano até o cearense.

No Semiárido, as áreas com densas matas serranas, lugares úmidos como a Serra do Ororubá, são chamados brejos de altitude. Espaços de disputas históricas entre os indígenas e os colonizadores, nos brejos nascem riachos e rios que mesmo intermitentes irrigam os sopés das serras e nos períodos de fortes chuvas correm em direção ao litoral, como o rio Ipojuca, ou o rio Ipanema que desagua no rio São Francisco. Sáo áreas também agricultáveis, onde lavouras para o consumo são plantadas pelos indígenas e os excedentes de frutas e verduras abastecem as feiras de cidades vizinhas como Arcoverde e Pesqueira.

Nos registros históricos já foi citada como "Ararobá, "Urubá” ou ainda "Ororubá". Sobre as origens da expressão; foram atribuídos vários significados: a corruptela de "üru-ibá", a fruta do "uru”, uma espécie de pássaro, portanto, a fruta do pássaro "uru”; ou também a corruptela de "arara-ubá", fruto da arara; sendo ainda a designação do povo indígena habitante naquele local, a Serra do Ororubá (MACIEL, 1980). 
A expansão na região do Agreste pernambucano ocorreu pelos caminhos ladeando dois rios que desaguam no litoral, o Capibaribe e o Ipojuca, este último nasce em terras da Serra do Ororubá. Seguindo a costa pelo "Caminho do Ipojuca", passava-se "pello arubá", como também era nomeado o local, seguindo para o Sertáo de Pernambuco, pelo vale do rio Moxotó, ou à direita, até o Sertáo da Paraíba. "A Estrada Real, que se iniciava no Recife e percorria o Vale do Ipojuca até o São Francisco, antigo caminho de boiadas" (Mello, 2004, p. 96-97). A Serra do Ororubá, onde foi fundada a Vila de Cimbres, é parte do complexo da Serra da Borborema, que se estende pela regiāo do Agreste, desde o Ceará até Pernambuco. Estudos apontaram que uma derivação da Borborema inicia exatamente em Pesqueira, espalhando-se por regióes vizinhas (Vasconcelos Sobrinho, 2005, p. 163-164).

Atendendo à legislação pombalina, o Governo da Capitania de Pernambuco, em 1761 determinou que: "A todas as vilas e lugares que erigir, denominará Vossa Mercê com nomes de Portugal" (FIAM/CEHM, 1985, p. 81). Assim, no antigo aldeamento do Ararobá, chamado de Nossa Senhora das Montanhas, e conhecido também como Monte Alegre, foi fundada, em 1762, a Vila de Cimbres, nome de povoação portuguesa no Distrito de Viseu. A partir dessa data e por todo o século XVIII, na documentação da Câmara de Cimbres encontram-se frequentes registros sobre os indígenas do antigo aldeamento do Ararobá.

Em 1777, a "Lista e translado do caderno das avaliaçóes dos dízimos desta vila de Cimbres", citava a presença de indígenas em diversas localidades - "sítios" - nas terras do aldeamento, apresentando um esboço da produção econômica dos aldeados. Foram relacionados nomes de índios do sexo masculino, possivelmente os chefes de famílias, que cultivavam milho, produziam farinha e criavam gado em apenas uma das localidades relacionadas (FIAM/CEHM, 1985, p. 146-149). São informações evidenciando o trabalho indígena naquela região no período colonial.

A Serra do Ororubá foi ocupada pelos criadores de gado disputando os espaços com as roças indígenas (Sette, 1956; Silva, 2017). Em 1853, o "Maioral de Cimbres" reclamou ao Diretor-parcial do aldeamento que as lavouras na "Serra do Urubá", como aparece citado na documentação, estavam sendo invadidas, "os gados no verão sobem a serra, e estragão as lavoiras, e os criadores recuzão fazer travessóens de serca, para evitar a subida dos gados”. Diante das reclamaçôes, a Presidência da Província reconheceu os direitos e acentuou a importância da grande produção indígena para o abastecimento daquela região, e ordenou ao Delegado de Polícia de Cimbres que obrigasse os criadores a cercar ou retirar o gado dos lugares cultiváveis "terreno que sempre foi destinado a plantaçóens, e que por sua extraordinária produção pode fazer a abundância de viveres naquele Certão". ${ }^{2}$

2 Ofício do Diretor Geral dos Índios, em 07/07/1853, ao Presidente da Província de Pernambuco. Arquivo Público Estadual de Pernambuco/APEJE, Códice DII-10, folha 22. 
Nos relatos das memórias orais, os Xukuru do Ororubá narraram sobre a época em que viviam da agricultura, período anterior às invasões da totalidade das terras pelos fazendeiros. Pedro Rodrigues Bispo, o Pajé conhecido por "Seu" Zequinha, nasceu e morou na atual Aldeia Cana Brava, relatou que os indígenas plantavam e coletavam espécies nativas:

Só existia o que plantasse. Uma mandioquinha, uma macaxeira, uma batata, um guandu, um pé de fava, um pé de cabuncuço, que era a comida dos índios era isso. Eu pequeno, não tinha outra coisa não. Um pé de banana, para botar o cacho de banana para comer dentro da fava cozinhada. E tinha o quê? Ou se não beiju! Pai arrancava a mandioca, ralava, espremia e fazia o beiju, para comer com.... É o que sei contar é isso. (Pedro Rodrigues Bispo, 2004).

Os relatos são de um passado vivido, desde a infância, portanto, unindo gerações, em que se fundamentam as memórias orais. "É esse passado vivido, bem mais do que o passado apreendido pela história escrita", sobre o qual se apoiam as memórias. "É nesse sentido que a história vivida se distingue da história escrita: ela tem tudo o que é preciso para construir um quadro vivo e natural em que um pensamento pode se apoiar, para conservar e reencontrar a imagem e seu passado" (Halbwachs, 2004, p. 75).

\section{As invasões dos fazendeiros e a novas formas do trabalho indígena}

$\mathrm{Na}$ região Agreste/Semiárido, com poucas chuvas anuais, os solos são rasos, pedregosos, com o domínio da Caatinga, a hidrografia intermitente onde ocorrem secas periódicas, muitas vezes calamitosas, agravando a baixa qualidade dos solos e a escassez dos recursos naturais disponíveis. No Vale do Ipojuca estáo localizados os brejos de São José e Ororubá, na Serra do Ororubá. Os brejos são pequenas faixas isoladas com solos profundos, matas de serras e cursos d'água permanentes, favorecendo a policultura tradicional, o plantio de feijão, mandioca, café, canade-açúcar, a horticultura e a fruticultura da banana, pinha, goiaba, caju, laranja, dentre outras (Melo, 1980, p. 173-175).

A fertilidade das terras na Serra do Ororubá foi sempre evidenciada. No "Diccionario Chorographico, Histórico e Estatístico de Pernambuco", publicado em 1908, o autor ressaltou: "Geralmente fraca no município, a agricultura, é futurosa na Serra do Ororubá pela uberdade de que oferece” (Galvão, 1908, 
p. 181). E destacando também a considerável produção agrícola de Cimbres, com cereais para abastecer as feiras da região. Plantava-se a cana-de-açúcar e existiam "algumas engenhocas de rapadura”. Terras férteis, “[...] o terreno é muito produtivo, principalmente na Serra de Ororubá, com abundante criação de gado, cavalos, ovelhas e cabras" (Galvão, 1908, p. 182). Os pequenos engenhos e o gado pertenciam aos fazendeiros invasores das terras indígenas. Naquela região, de clima predominante seco, as disputas pelos locais úmidos e pelas fontes de água eram intensas. A expansão pastoril foi cada vez mais acentuada, restringindo as lavouras para o consumo, pois os espaços eram usados como refrigério para o gado, em períodos de longas estiagens.

Um abaixo-assinado dos "índios da extinta Aldeia de Cimbres", com 192 assinaturas, foi enviado, em 1885, ao Presidente da Província de Pernambuco. Os signatários, apelando para o senso de justiça, solicitavam providências para "fazer cessar as perseguiçôes de que são vítimas”. Informavam que as terras públicas, onde habitavam, estavam sendo invadidas por "verdadeiros intrusos". Os índios afirmavam que se ocupavam "exclusivamente do trabalho da agricultura", denunciando as invasôes por fazendeiros. Um fazendeiro fugindo da seca na Paraíba invadiu as áreas mais férteis na Serra do Ororubá, com o gado destruindo as roças dos indígenas que afirmavam, por serem pobres, estarem sendo explorados e não sendo ouvidos em suas queixas pelas autoridades policiais.

Os fazendeiros perseguiam os queixosos, que eram presos e processados. Como acontecera com Manoel Felix Santiago, líder do abaixo-assinado: "por não ter cedido do seu direito" fora preso, mas absolvido. Os índios afirmavam que, com a extinção do aldeamento, o Governo Imperial determinara "a demarcação dos terrenos que lhe eram pertencentes". Mas, embora tendo sido publicados os editais, pela Tesouraria da Fazenda, para propostas de agrimensores executores da medição, até aquela data não fora reconhecida, sendo as terras invadidas por "intrusos", fazendeiros criadores de gado, destruidores das lavouras dos índios, "para que assim os suplicantes perseguidos abandonem as suas antigas e legítimas posses!!”. ${ }^{3}$

A extinção oficial em 1879 do antigo Aldeamento de Cimbres, consolidou o domínio dos fazendeiros invasores nas terras da Serra do Ororubá. Uma ou outra família indígena ficou em pequenos pedaços de terras, insuficientes para a sobrevivência. Vários indígenas relataram essa situação. A índia Laurinda Barbosa dos Santos, conhecida por "D. Santa”, era moradora na atual Aldeia Caípe. Os pais nasceram na "Serra", o pai em Pendurado e a mãe em Caípe, local onde,

3 Ofício do Diretor Geral dos Índios, em 07/07/1853, ao Presidente da Província de Pernambuco. Arquivo Público Estadual de Pernambuco/APEJE, Códice DII-10, folha 25. 
depois de casados, moraram. "D. Santa" afirmou ainda que trabalhou na roça desde oito anos. Questionada se os moradores e parentes vizinhos tinham terras para plantar, afirmou: "Tinham bem pouquinha! Porque não podia comprar. Naquele tempo tudo era comprado e ninguém podia, os pais de nós não podia que era tudo pobrezinhos. Só vivia trabalhando no alugado que era para dar de comer aos filhos. Era terras dos fazendeiros" (Laurinda Barbosa dos Santos, 2005).

Outros entrevistados, em diferentes localidades na Serra do Ororubá, também confirmaram a falta de terras para trabalho. Como "Seu" Cassiano, nascido e vivendo na Aldeia Cana Brava, afirmando que o pai "[...] tinha 4 quadros de terras. Não dava para viver. Não dava porque ele trabalhava alugado. Ele só no alugado coitado, se entertia naquilo". Isso porque: "Aqui todo mundo era dono de pequenos pedaços de terras, cercado de fazendeiros, Zé Zacarias, Arlindo Sabino, Bernardo, Zé Marques, Antônio de Zumba. Tinha gado e sítio. No Sítio do Meio era terra de gado, por todo o canto era gado!" (Cassiano Dias de Souza, 2005).

Ainda em Cana Brava, outro entrevistado, cujos pais nasceram e viveram no local, relatou sobre as dificuldades do acesso à terra para o trabalho, com a exploração e pressão dos fazendeiros:

A dificuldade era grande. Desde o meu tempo, eu caí no trabalho da agricultura com dez anos de idade! Porque o ramo dos meus pais, dos meus avós, tudo era trabalhar na agricultura. Mas não existia terra para trabalhar! Não existia terra para trabalho. Nós trabalhava arrendado com fazendeiro. Você botava meio hectare de terra ou um hectare. Fazia a broca, fazia a terra, plantava, quando a lavoura, quando nós plantava que nascia, o fazendeiro já danava capim dentro! Nós trabalhava arrendado! Porque ali não desfrutava nada! Quando tava começando a desfrutar, ele já botava o gado dentro! Pronto, acabava com tudo, nós ficava sem nada. (Juvêncio Balbino da Silva, 2005).

$\mathrm{Na}$ Aldeia Brejinho, a situação era semelhante. Ao ser perguntado se os pais tinham terras para trabalho, "Seu" Malaquias afirmou que trabalhavam somente em terras nas mãos dos fazendeiros:

Terra tinha na fazenda. Própria não. Tinha a moradia. Plantavam um ano ali num lugar cercado, plantava milho, feijão, plantava o que quisesse esse ano, e outro ano, mudava lá outro cercado. Agora nesse ano trabalhava aqui plantava capim e aqui não trabalhava mais, aí mudava para outro, botava os roçados, botava o capim, mudava para outro. (Malaquias Figueira Ramos, 2005). 
A opção para os índios sem terras era o chamado trabalho alugado. E aumentava a pressáo dos fazendeiros sobre aqueles que possuíam pequenos pedaços de terras, arrendando-as, comprando-as, tomando-as a força. Provocando a dispersão de famílias indígenas:

E pagava a renda com a planta do capim ou da palma. Era. E o índio tinha que fazer aquilo mesmo. E eles aqueles, os índios que tinham um pedacinho de terra, ai foram apertando, os fazendeiros foram apertando, foram apertando e eles tudo de boca aberta, nem davam o roçado, nem arrendava e nem nada. Eu compro seu pedacinho de terra e eles besta comprava, vendia ou vendia. Vou sair daqui que doutor fulano vai tomar conta disso aqui e depois pode dele não querer pagar e nós perde, vendiam. Vendiam e iam pra rua e outros ia s'imbora pelo mundo, por aí afora, vivia por esses cantos. (Gercino Balbino da Silva, 2004).

Em outras localidades, algumas famílias herdaram dos antepassados pequenos pedaços de terra: "Meu pai tinha um pouquinho de terra, pouquinho. É três hectares e meio, a terra do meu pai. Foi herança da minha máe. Ainda hoje eu tenho essa terra, ainda eu possuo essa terra. Têm umas terras pequenininhas, todos eles moram numa terra bem pequenininha mesmo" (Milton Rodrigues Cordeiro, 2005).

O Pajé Xukuru, narrou que sem terras os índios eram obrigados a trabalhar para os fazendeiros. O próprio trabalhou nessas condiçóes. Quando era de interesse, os fazendeiros cediam terras para trabalho em regime de pagamento com a maior parte da produçáo colhida às pressas. Uma pressão crescente até a expulsão dos pequenos proprietários:

Quem ficou com uns pedacinhos, ainda trabalhava naqueles pedacinhos deles e quem não tinha, tinha que trabalhar a roubo. $O$ pessoal, o fazendeiro abria campina, andava aquele roçado. Eu mesmo trabalhei muito nas propriedades do povo, dos fazendeiros. Eu pagava um saco de milho por quadra, pagava. O pagamento era um saco de milho e a prestaçáo ficava. Fechava pra estação e a fava que a gente ficava, ele náo deixava nem amadurecer direito, o camarada apanhava verde mesmo, ai que nós vivia assim, mas teve uma época, que não teve nada. Os fazendeiros tomaram conta. (Pedro Rodrigues Bispo, 2004).

E ressaltou que os despossuídos de terras eram os mais oprimidos pelos fazendeiros, que soltavam o gado no plantio, antes do término da colheita: 
Esses é que sofriam demais! Onde trabalhar? Só era do fazendeiro fazer deles o que queria. Dava um pedacinho de terra deste tamanho assim para trabalhar, não deixava a fava criar nem caroço, nem secar, apanhava verde, o milho quebrava verde, ainda o leite correndo pro gado não comer. 'Vou botar o gado!'. Muitos já quebrava com o gado dentro! O fazendeiro botava, cada vez mais apertava a dobradiça. (Pedro Rodrigues Bispo, 2004).

Os relatos sobre as relaçôes de trabalho na condição de moradores nas terras por anos em mãos dos fazendeiros, também foram narrados ainda por "Seu" Juvêncio:

Quem não tinha terra, morava de favor, morava com os brancos, eles botava lá. Eles botava eles para morar, dava uma moradia a eles, botava eles para morar e prá trabalhar eles direto!' Trabalhar eles direto! Nunca teve futuro. Eu mesmo trabalhei muito para outros. Trabalhei muito alugado. Eu trabalhei de 1952 para cá, eu morei com o fazendeiro aqui Antônio Zumba, era o homem mais rico dessa regiāo! O nome dele era Antônio Zumba. Agora que ele era muito bom. Ele era muito bom. O nome dele era Antônio Zumba. Só com ele eu trabalhei 32 anos. (Juvêncio Balbino da Silva, 2005).

Como relatou "Seu" Gercino, com a apropriação das terras pelos fazendeiros, passou a existir o morador-trabalhador por toda a Serra do Ororubá; "Morador tinha em todo canto aqui em cima da Serra, em todo canto dos fazendeiros" (Gercino Balbino da Silva, 2004).

\section{A "juntada": o trabalho em mutirão. As migrações para trabalho}

Espremidos nos pequenos sítios, como moradores ou trabalhando nas fazendas e nos engenhos, por meio dos mutiróes, das festas e das novenas realizadas em vários locais, na Serra do Ororubá, os Xukurus teceram e vivenciaram laços de solidariedade:

Naquela época se chamava sítio, viu? Sítio Cana Brava, Sítio Pé-de-Serra, Sítio Oiti, Sítio da Vila, era assim por diante. Agora, hoje, não, hoje já tá batizado por aldeia, é conhecida mesmo no livro, escrevida como aldeia. Naquela época tinha duas Cana Brava: Cana Brava de Dentro, Cana Brava de Fora. Tinha Sítio Canivete, tinha Sítio Sabiá, tinha Sítio Lagoa, 
tinha Sítio Caíque, tinha Sítio Gitó, tinha Sítio Pedra D’Água, tinha Sítio Santana. Tinha Sítio Brejinho, tinha Sítio Caípe, tudo era sítio. (Cícero Pereira de Araújo, 2002).

O "sítio" significava também o espaço de moradia para famílias em pequenos lotes conjugados, herdados dos antepassados, com os limites confundidos pelas relaçóes de parentela de irmãos/as, cunhados/as, tios/as e primos/as. Uma das formas em que o sítio também era um espaço de relaçóes sociais, ocorreu nos "ajuntados", "juntada" ou ainda "adjunto", como os Xukuru do Orourbá chamam o trabalho em mutirão na roça. Nascido e morador por muitos anos em Cana Brava, "Seu" Ciço Pereira relatou que a festa, após o trabalho, solidificava a proximidade entre todos. E para o trabalho em mutiráo, o dono do roçado fornecia a alimentação aos participantes:

Na seca dessa época, os índios aqui em cima dessa Serra aqui. Eles trabalhavam. Se chamava juntada. O índio tinha um roçado muito grande, dizia tal dia, eu vou botar uma juntada. Aqueles mais interessados perguntava: - quantos você vai querer? - Vou querer dez ou doze, quinze ou vinte homens. Os que puder ir. Eles iam, juntava aquela turmona. Se fosse de enxada era de enxada, se foice era de foice, se fosse de enxadeco era de enxadeco. "Pronto, vou fazer esse serviço aqui". "Vamos fazer". Balançavam o enxadeco pra cima. Ele dava o café bem cedo, dava a hurinca (bebida), dava o almoço e dava o jantar pra aquele povo todo, podia ser o que fosse. Metia a enxada pra cima, até num dia virava tudo. Eita, acabou! Era aquela farra e tal e vira e mexe. (Cícero Pereira de Araújo, 2002).

O trabalho em mutirão significava a reciprocidade. Pois, quem convidava deveria participar dos demais mutiróes e assim todos se ajudavam, como afirmou "Seu" Gercino:

Tal dia nós vamos pra fulano de tal, tal dia nós vamos pra mim. Então, assim nós vivia. Cansei de trabalhar em juntada. Caboclo se ajudava aos outros assim, botava um adjunto. Assis Pereira mesmo botou adjunto que ele era mais forte, uma coisinha podia botar. Finada Joana Batista nessa juntada dela, tinha duzentos e sessenta e dois. (Gercino Balbino da Silva, 2004).

Nas memórias orais dos Xukuru do Ororubá, são citadas as migraçóes dos índios para a Zona da Mata Sul, o chamado "Sul", em períodos de seca ou longas estiagens, buscando trabalho. A seca que nos anos 1950 atingiu o Agreste, provocou a migração para o "Eldorado", uma referência aos estados no Sudeste 
e Sul do país. Os agentes do Serviço de Proteção aos Índios (SPI) ressentiam-se da falta de recursos para socorrer os flagelados das secas periódicas e sucessivas na região. ${ }^{4}$ Índios com as famílias, a exemplo dos indígenas Xukuru do Ororubá, procuravam os postos nas aldeias ou a diretoria do SPI no Recife e parcialmente atendidos, migravam. No conhecido livro "A terra e o homem no Nordeste", publicado em 1963 e reeditado várias vezes, o autor, Manuel Correia de Andrade, classificou dentre os trabalhadores assalariados na lavoura canavieira "os corumbas" ou "catingueiros", do Agreste e Sertão, mas que se deslocavam "todos os anos para a zona canavieira durante a safra, a fim de participar da colheita. Fazem, assim, uma migração sazonal, uma vez que com as primeiras chuvas voltam para sua terra" (Andrade, 1980, p. 106).

Nascido e morador na atual Aldeia São José, onde em 1944 foi instalado o posto do SPI, "Seu" Zé Pedro relatou que "quando faltava serviço", foi trabalhar na construção das barragens de Paulo Afonso e Sobradinho, na Bahia. E viajou, com o mesmo objetivo, para São Paulo e Campina Grande, na Paraíba. Membro da antiga Família Simplício, habitantes em São José, o indígena gostava de ir mesmo era para "o sul", lugar "animado", na época da colheita, onde ficou durante anos seguidos: "Eu gostava muito do 'sul'. Cortar cana. Brincar por lá... O 'sul' é muito animado demais. No tempo da moagem é mesmo que festa! Eu terminei no Sul de Alagoas. E já vim faz pouco tempo, que vim de lá. Eu vim me aposentar! Fui plantar verdura mais um doutor lá" (José Pedro Simplício, 2004).

Outro entrevistado morador na Aldeia Cana Brava relatou: "Fui trabalhar em Alagoas no caminhão de cana. Porque aqui não tinha o que nós ganhar. Quem pagava aqui um serviço era os que podia. Fui trabalhar no sul, em Alagoas. Trabalhei no caminhão de cana. Fui uns 5 ou 6 anos" (Manoel Balbino Silva, 2005).

"Seu" Zequinha, em períodos de estiagem sem produção na lavoura, também viajou para o "sul": "Às vezes nessa época aqui dava seca, não tinha onde trabalhar. Aí ía para o Sul. Para a área da cana. Eu trabalhei na Usina Pedrosa, trabalhei na Usina Catende. Ia e voltava. Ia na época da safra. Somente, quando tava seco aqui. As vezes dava pouco dinheiro, eu ia lá dava um dinheirinho mais melhor" (Pedro Rodrigues Bispo, 2004).

Quando os fazendeiros soltavam o gado nas roças indígenas, antes da colheita, os índios buscavam trabalho fora da Serra do Ororubá. Além do "sul", alguns índios foram trabalhar na colheita do algodão no sertão da Paraíba. O Pajé trabalhou apenas na lavoura da cana: “'Vou botar o gado!'. Muitos já quebrava

Ofício da IR4, em 30/05/1956, para a Diretoria do SPI/RJ. Rio de Janeiro, Museu do Índio/Sedoc, microfilme182, fotograma 073. 
com o gado dentro! O fazendeiro botava, cada vez mais apertava a dobradiça. Por isso muita gente ia pro 'sul', muita gente foi para o algodão. Eu nunca fui, não. Só fui pro 'sul'. Pro 'sul' fui, fui de solteiro, fui umas quatro vezes. De casado eu só fui uma vez" (Pedro Rodrigues Bispo, 2004).

O percurso até "o sul" era caminhando pelas matas, em grupos ou sozinho:

Ia de pé até Bezerros. Bezerros deixava o trem e entrava de pés na linha de Camocim. De Camocim não, de Bezerros nós tirava de pés para lá. Nós ficava um dia um dia, e pouco. Nós ia muito devagar. Ia pelas matas, sentando. Aí gastava mais de um dia. Cansei de ir eu e um colega meu, somente nós dois. Nunca gostei de andar de tuia. Uma vez foi 20 num grupo. De outra vez foi 25. Mas eu não gostava de andar de grupo, não. (Pedro Rodrigues Bispo, 2004).

No "sul", os índios trabalhavam em atividades na usina ou no corte da canade-açúcar. O trabalho era dia e noite:

Lá trabalhava a noite na usina. Durante o dia, quem ia para o corte de cana, era para corte da cana. Quem trabalhava na usina era na usina. Porque tinha duas turmas. Uma pegava de meio-dia para meia-noite, outra pegava de meia-noite para meio-dia. Agora o meu serviço, eu trabalhava mais de dia. Trabalhei no armazém de açúcar. Trabalhei na esteira também, mas foi pouco tempo. Aí eu fui para o armazém. Trabalhei no armazém, eu trabalhei nas turbinas, turbinando o açúcar. Eu trabalhei no adubo, traçando adubo para cana. (Pedro Rodrigues Bispo, 2004).

O pouco dinheiro recebido compensava, sem maiores perspectivas na Serra do Ororubá. No "sul", o trabalho era clandestino: "Prá gente que naquela época que a gente ganhava aqui nada, ia pra lá dava pra ganhar mais um troco. Não tinha carteira assinada. Eu não trabalhei de carteira assinada. Era clandestino" (Pedro Rodrigues Bispo, 2004).

A falta de chuvas e a fome motivaram "Seu" Floriano a deixar a família na Serra do Ororubá e ir para "o sul", com outros índios, trabalhar na colheita e moagem da cana:

Eu saí para trabalhar fora, para ganhar dinheiro. No sul, na Usina Pedrosa. Fui trabalhar, sai daqui no tempo ruim, eu deixei a mulher... Eu digo, 'eu vou pro sul, senão eu me acabo de fome!' É que fui pra lá. Trabalhei lá uns três meses ou quatro. Adepois que voltei melhorou a situação, choveu...Prá gente plantar. Foi muita gente. Daqui foi muita gente. Num comboio eu 
acho que ia bem uns catorze para lá. Era tempo de seca. Era para moer cana, da moagem de cana. (Floriano Marcolino da Silva, 2005).

A viagem de ida era realizada a pé, pois não tinham sequer recursos para a passagem de trem, só na volta. Trabalhavam na colheita e na moagem da cana:

Ia a pé até lá mesmo. Não pegava trem não. Com quê?? Passava três dias ou quatro para chegar lá. A volta melhorou uma coisinha, porque a gente ganhou um trocadinho, a gente peguemos, viemos até Caruaru de pé. De lá nos peguemos o trem e cheguemos até aqui. Uma vida dura. Lá era para plantar cana, para cortar cana, era para moer cana. (Floriano Marcolino da Silva, 2005).

Sem terras, "Seu" Malaquias trabalhava para um fazendeiro. Depois foi para o Recife, "o sul" e Alagoas. Aprendeu a trabalhar em outras profissóes na capital pernambucana. Cortou cana para várias usinas que buscavam os índios em caminhóes, na época de seca na Serra do Ororubá e de moagem da cana no "sul":

Eu mesmo passei três anos no Recife para Alagoas. Quando eu deixei a fazenda, eu passei mais de três anos pelo mundo trabalhando. No Recife, no sul, Alagoas. Eu tenho uma arte. Eu trabalhava na agricultura aqui. Mas lá eu trabalhava em arte: pintor de azulejo, de armador, de encanador. E no sul era cortando cana e espalhando cana. O caminháo ia e levava cheio! Para Caetés, Cucau, Palmares, Barreiros...Vinha nessa época de setembro, quando começa a seca. Nós ia pra lá. (Malaquias Figueira Ramos, 2005).

Muitos Xukurus também migraram para o Sertão da Paraíba, onde foram trabalhar nas lavouras de algodão. "Seu" Malaquias também colheu algodão em várias localidades paraibanas. Diferente do trabalho no "sul", recebiam alimentação e estadia:

Eu ia na época da safra de algodáo, de agosto pra setembro, as vezes chegava lá em setembro. Perto de Monteiro. Paraguai, Contrapina. Era tudo perto de Monteiro, a gente ia. Lá os patrão dava bóia: o almoço, a janta, a dormida, que a gente ganhasse era livre. Não tinha história de fazer feira não. O pouco que a gente ganhasse era livre. (Malaquias Figueira Ramos, 2005).

No Sertão da Paraíba trabalhavam na colheita de algodão ou em regime de divisão da produção com os fazendeiros. Para o "sul" foi caminhando, por falta de dinheiro para pagar um transporte. $\mathrm{O}$ entrevistado não foi, mas um seu irmão trabalhou em usinas e voltou para casa com um pouco de dinheiro: 
E lá trabalhava para fazendeiros, plantava algodão, trabalhavam de meia com o patrão. Quando o tempo estava meio ruim pegavam o campo lá para apanhar algodão dos fazendeiros. Tempo de seca, porque às vezes botava roçado e perdia. A seca braba, perdia, ia atrás do algodão na Paraíba, no Sertão. No Sul ia cortar cana. Na Usina Pedrosa, Barreiros... Ia a pé. Não tinham dinheiro para pegar um jegue. Saía da Serra, trabalhava lá um mês, dois e quando acabava voltava. Ia a pé até chegar na Usina. Ia no mês de outubro para novembro, de setembro para outubro. Eu não fui, mais um irmão meu ainda foi. Ele foi para a Usina Barreiros, voltou com um troquinho pouco [risos]. (Malaquias Figueira Ramos, 2005).

Apesar das condiçóes diferenciadas, em caso de acidentes de trabalho as condiçóes para um socorro eram precárias em razão das distâncias. Em comparação com a lavoura canavieira, colher algodáo era uma atividade mais leve, como afirmou outro indígena:

Davam tudo. Davam dormida, dava comida, dava tudo. Ia daqui trabalhar, quando trabalhava que vencia o tempo vinha embora. Aleijado, ou manquejando, ou marcando, tinha que se cuidar. Se fosse um negócio prá medico, era longe três léguas pro cabra ir. Como é que o cabra ia de pé? Não tinha transporte. Existia mas era carro de boi, pronto e outra coisa, nada. Porque o trabalho da gente lá era, num era complicado, era de algodão. As vezes fazia uma cerca, era o mais complicado, mas não. Era somente catar algodão. (Gercino Balbino da Silva, 2004).

$\mathrm{Na}$ falta de recursos financeiros, se deslocavam também a pé para as lavouras do algodão, na Paraíba, "Daqui nós ia de a pés prá Paraíba. Ia daqui de Cana Braba mesmo, os conhecidos dali de Cana Braba" (Gercino Balbino da Silva, 2004).

\section{De agricultores a operários nas fábricas}

O estudo de um geógrafo em 1956 sobre Pesqueira, descrevia a localidade como uma regiáo onde, durante boa parte do ano, predominava a seca. $\mathrm{O}$ gado dividia o espaço com lavouras e plantações de tomate. As citadas lavouras eram os sítios, pequenas glebas de terras espremidas entre as áreas de criação das fazendas, que permaneciam nas mãos de umas poucas famílias indígenas. $\mathrm{O}$ mesmo estudo apontava o desmatamento recente para a lavoura de cafezais, plantaçóes de 
goiabeiras, bananeiras e outras frutas, destinadas às fábricas de doces em Pesqueira (Sette, 1956, p. 8-12). Uma lógica econômica baseada na criação de gado ou na agroindústria substituiu a produção de alimentos, expulsou a maioria ou confinou alguns pequenos agricultores, os índios habitantes na Serra do Ororubá. Um número considerável deles foi forçado a abandonar os antigos locais de moradia e se concentrar na periferia da cidade. Outros passaram à condiçáo de mão-de-obra para as fábricas, como fornecedores de matéria prima ou como operários.

A cidade cresceu, impulsionada pelo comércio, beneficiada pela sua localização estratégica. As transações envolviam mercadorias do Sertão, de vários lugares vizinhos no Agreste, de municípios da Paraíba e até de Alagoas. Compras e vendas de algodáo, mamona, couros, peles de cabra e produtos agrícolas da Serra do Ororubá, em um intercâmbio constante com o litoral, tendo como destino mais preciso o Recife. O anuário comercial de 1902/3, publicado no Recife, registrava 23 casas comerciais em Pesqueira, que vendiam secos e molhados em grosso e a varejo (Sette, 1956, p. 53).

O transporte de trem rápido e barato a partir de 1907, possibilitou à fábrica de doces Peixe ampliar a produção para novos mercados. Ocorreu a adoção de inovaçóes tecnológicas e o surgimento de uma outra indústria doceira, a fábrica Rosa. As frutas destinadas à indústria de doces provinham da Serra do Ororubá, onde multiplicaram-se os plantios de goiabas e bananas. As fazendas de gado estimularam o surgimento de fábricas de laticínios. Por volta de 1914, foi iniciado o beneficiamento do tomate, pela fábrica Peixe, necessitando de áreas para o plantio do produto. Ampliava-se o parque industrial, com a instalação de mais unidades da Peixe e novas fábricas, como a Tigre, Paulo de Brito, Peixinho, Recreio (Sette, 1956, p. 64-65).

Durante a colheita das grandes safras, nas fábricas em Pesqueira trabalhavam muitos índios, mas sem vínculo empregatício. Trabalho duro e considerado sujo, no período noturno, para fugir à fiscalização trabalhista:

Muitos sem carteira assinada. A noite tinha uma história de uma "virada", chamava-se "a virada", os "porcos" porque trabalhava no leite, de noite, na tomate. Serviço sujo, aí chamavam assim. Quando a safra era grande, quando a fábrica não vencia para trabalhar só o dia. Aí tinha que trabalhar à noite porque era muita polpa. (Pedro Rodrigues Bispo,2004).

As "viradas", como era chamado o trabalho noturno, era um serviço pesado, sem os direitos trabalhistas, como recordou outro entrevistado: "Trabalhei nas viradas. As 'viradas' parece que era três mil reis ou era quatro mil reis. Era de noite. A gente ia trabalhar de noite. Serviço pesado, carregar caixas nas costas, 
descarregar caminhão, todo molhado. Sem registro. Tempo difícil” (Floriano Marcolino da Silva, 2005).

Um entrevistado lembrou dos índios no serviço noturno de carga e descarga nos muitos caminhôes com tomate, sem vínculo empregatício:

Era muita gente que trabalhava na fábrica Peixe, mas era índio, tudo índio daqui da Serra. Era de vinte, trinta, vinte. Era de vinte, de quinze pra lá que ia. Toda viagem que ia pra fábrica Peixe toda noite. Mas eles iam fazer sabe o que? Iam trabalhar a noite. Num era trabalhador fichado náo. Iam carregar coisas nas costas, tomate. Descarregar caminhão todo, que era a fábrica Peixe lutava com cento e tanto caminhão, viu! Carregando tomate. (Cícero Pereira de Araújo, 2002).

O trabalho era temporário. A fábrica Peixe demitia antes de completar um ano por questôes dos direitos trabalhistas, como afirmou o entrevistado: "Depois que trabalhava um ano, nós saía. A derradeira vez que eu entrei, passei 7 anos sem sair. Passei por lá direto". Indagando os motivos do afastamento, ouviam da chefia a resposta: "Quando for tempo vocês voltam pro trabalho". E se fosse procurar o sindicato eram demitidos sumariamente:

Nós pagava Sindicato. O Sindicato não servia para nada. Só servia o INPS. A gente pagava o Sindicato e não valeu de nada. Quando o Sindicato ia botava nós para fora. Por isso eu acredito que não valia nada. Bateu no Sindicato, o Sindicato chegou, rua! Para mim não valeu a pena! Para mim foi perdido, nós pagava perdido. (Cícero Pereira de Araújo, 2002).

O entrevistado relatou ainda que a fábrica Peixe possuía muitos plantios de tomates em várias localidades próximas de Pesqueira e a colheita de frutas se concentrava na Serra do Ororubá, em terras invadidas pelos fazendeiros e também nas pequenas glebas de indígenas fornecedores da matéria prima para a agroindústria.

A agroindústria instalada em Pesqueira entrou em decadência em fins dos anos 1960. As fábricas foram fechando e a situação se acentuou na década seguinte, em consequência das sucessivas pragas que atingiram a lavoura do tomate, apesar do intenso uso de agrotóxicos que provocaria grave degradação das terras na regiáo. As secas prolongadas ou a escassez de água agravada após os desmatamentos em áreas destinadas aos plantios, também contribuíram para a decadência da agroindústria. Com as mudanças econômicas, os grandes capitais passaram a ser investidos no Sudeste do país, em fábricas concorrentes; ocorrendo a desagregação das famílias proprietárias das fábricas. A maior delas, a fábrica 
Peixe, foi vendida a um grupo canadense, chegando, por fim, à falência em fins dos anos 1990 (Cavalcanti, 1979).

\section{Produção agrícola orgânica: novas forma de trabalho Xukuru do Ororubá}

Os trechos citados das entrevista com os indígenas são fragmentos de relatos individuais, de memórias autobiográficas, mas que fazem parte de uma história coletiva, na medida em que toda memória individual se apoia na memória grupal, pois toda história de vida faz parte da história em geral (Halbwachs, 2004, p. 59). Nos relatos das memórias orais dos Xukuru do Ororubá, foi possível perceber o trabalho próprio na agricultura, para os fazendeiros invasores das terras indígenas ou como operários na agroindústria, em Pesqueira. E ainda nas atividades exercidas, por falta de terras e em razão da seca, na lavoura canavieira na Zona da Mata Sul pernambucana e Norte alagoana, ou nas plantaçóes de algodão no Sertão paraibano. Em relatos que compartilharam experiências das diferentes e variadas formas trabalho, a partir do vivido, do concebido e do expressado (Alberti, 2004).

Em fins de 1990, o povo indígena Xukuru do Ororubá, a despeito das muitas perseguiçóes e violências, liderado pelo conhecido Cacique "Xicão", que em maio de 1998 foi assassinado a mando de fazendeiros, se mobilizou e retomou as terras invadidas pelos latifundiários, conquistando a demarcação oficial do território indígena em 2001. Após as retomadas das terras, os indígenas retomaram a agricultura para o consumo, o plantio da roça baseada no milho e feijão e ainda com a mandioca, a macaxeira e as batatas, como é comum no Semiárido nordestino.

Um grupo de famílias Xukuru do Ororubá, na regiáo da Serra com maior umidade e fontes de água por mais tempo, mesmo em longos períodos de estiagens, vêm realizando o plantio orgânico de legumes e verduras, colocados à venda e disputados pelos consumidores nas feiras livres, semanalmente, em Pesqueira, nas instalaçóes onde funcionava a fábrica Peixe e também na vizinha cidade de Arcoverde.

Chegamos em 2011 com um grupo de 20 famílias que comercializam sua produção em espaço diferenciado, dedicado somente à produção ecológica Xukuru, conquistado dentro da feira livre da cidade, duas vezes por semana. Localizada agora no pátio de uma antiga fábrica de doces e derivados de tomate, parece ser uma feliz e irônica resposta "geográfica" aos anos de 
difusão do modelo "moderno" de agricultura, no qual se inclui a difusão de técnicas convencionais, a dependência de insumos externos e a concentração de terra. (Araújo; Ordonio, 2011, p. 2).

São escassos os registros, análises e reflexões acerca dessa recente e nova forma do trabalho dos indígenas. Sobre como denominam a "Agricultura dos Encantados", vinculando o trabalho na terra com a dimensão religiosa e atribuição sagrada da Natureza, morada dos "Encantados", os seres míticos do panteão religioso indígena. Com a demarcação definitiva, os Xukuru do Ororubá iniciaram uma experiência de cultivos agroecológicos com resultados exitosos, o que, como relatam e é facilmente observado, vem garantido a recuperação do solo, o vicejar de matas, o retorno da fauna e o trabalho na agricultura para a vida com dignidade, para afirmação da identidade no Semiárido indígena pernambucano.

\section{Referências}

ALBERTI, Verena. Ouvir contar: textos em História Oral. Rio de Janeiro: FGV, 2004.

ANDRADE, Manuel Correia de. A terra e o homem no Nordeste. 6. ed. Recife: Editora Universitária da UFPE, 1980.

ARAÚJO, André Luís de Oliveira; ORDONIO, Iran Neves. Feira Xukuru do Ororubá: conquistas em torno de uma experiência de comercialização de alimentos de base ecológica. Cadernos de Agroecologia, v. 6, n. 2, p. 1-5, dez. 2011.

ALMEIDA, Maria Regina Celestino de. Metamorfoses indígenas: identidade e cultura nas aldeias coloniais do Rio de Janeiro. 2. ed. Rio de Janeiro: FGV, 2013.

CAVALCANTI, Célia Maria de Lira. Acumulação de capital e a industrialização em Pesqueira (Pernambuco). Dissertação (Mestrado em Economia) - UFPE, Recife, PE, 1979.

DANTAS. Mariana Albuquerque. Dimensóes da participação política indígena. Estado nacional e revoltas em Pernambuco e Alagoas, 1817-1848. Rio de Janeiro: Arquivo Nacional, 2018.

FIAM/CEHM. Livro da Criação da Vila de Cimbres: 1762-1867. Recife: FIAM-CEHM, Prefeitura Municipal de Pesqueira, 1985. 
GALVÃO, Sebastião de Vasconcellos. Diccionario chorographico, histórico e estatístico de Pernambuco. Rio de Janeiro: Imprensa Nacional, 1908.

HALBWACHS, Maurice. A memória coletiva. São Paulo: Centauro, 2004.

MACIEL José de A. Pesqueira e o antigo Termo de Cimbres. Recife: CEHM, 1980.

MEDEIROS, Maria do Céu. Igreja e dominação no Brasil escravista: o caso dos Oratorianos de Pernambuco (1659-1830). João Pessoa: Ideia, 1993.

MELO, Mário Lacerda de. Os Agrestes. Recife: SUDENE, 1980.

MELLO, José Antônio Gonsalves de. de. Três roteiros de penetração no território pernambucano (1738 e 1802). In: . Da Inquisição ao Império. Recife: Editora Universitária da UFPE, 2004. p. 87-113.

MONTEIRO, John Manuel. Negros da terra: índios e bandeirantes nas origens de São Paulo. São Paulo: Companhia das Letras, 1994.

SETTE, Hilton. Pesqueira: aspectos de sua Geografia Urbana e de suas interrelaçóes regionais. Tese de concurso para provimento de efetivo da cadeira de Geografia do Brasil do Colégio Estadual de Pernambuco. Recife: 1956.

SILVA, Edson. Xukuru: memórias e história dos índios da Serra do Ororubá (Pesqueira/ PE), 1959-1988. 2. ed. Recife, EDUFPE, 2017.

SILVA, Edson Hely. O lugar do indio. Conflitos, esbulhos de terras e resistência indígena no século XIX: o caso de Escada-PE (1860-1880). Dissertaçáa (Mestrado em História) UFPE, Recife, PE, 1995.

VASCONCELOS SOBRINHO, José de. As regiöes naturais do Nordeste, o meio e a civilização. Recife: Condepe, 2005.

\section{Fontes orais}

ARAÚJO, Cícero Pereira de [81 anos]. [jan. 2202]. Entrevistador: Edson Silva. Pesqueira, Bairro Xucurus, PE, 5 jan. 2002.

BISPO, Pedro Rodrigues [72 anos]. [mar. 2004]. Entrevistador: Edson Silva. Pesqueira, Bairro Baixa Grande, PE, 29 mar. 2004. 
CORDEIRO, Milton Rodrigues [57 anos]. [jul. 2005]. Entrevistador: Edson Silva. Pesqueira, Aldeia Gitó, Serra do Ororubá, PE, 4 jul. 2005.

RAMOS, Malaquias Figueira [62 anos]. [nov. 2005] Entrevistador: Edson Silva. Pesqueira, Aldeia Brejinho, PE, 17 nov. 2005.

SANTOS, Laurinda Barbosa dos [89 anos]. [nov. 2005]. Entrevistador: Edson Silva. Pesqueira, Aldeia Caípe, Serra do Ororubá, PE, 12 nov. 2005.

SILVA Floriano Marcolino da [90 anos]. [dez. 2005]. Entrevistador: Edson Silva. Pesqueira, Aldeia Cana Brava, Serra do Ororubá, PE, 17 dez. 2005.

SILVA, Gercino Balbino [80 anos]. [ago. 2004] Entrevistador: Edson Silva. Pesqueira, Aldeia Pedra d’Água, Serra do Ororubá, PE, 11 ago. 2004.

SILVA, Juvêncio Balbino da [76 anos]. [dez. 2005] Entrevistador: Edson Silva. Pesqueira, Aldeia Cana Brava, Serra do Ororubá, PE, 15 dez. 2005.

SILVA, Manoel Balbino da [73 anos]. [nov. 2005]. Entrevistador: Edson Silva. Pesqueira, Aldeia Cana Brava, Serra do Ororubá, PE, 17 nov. 2005.

SIMPLíCIO, José Pedro [75 anos]. [jul. 2004]. Entrevistador: Edson Silva. Pesqueira, Aldeia São José, Serra do Ororubá, PE, 5 jul. 2004.

SOUZA, Cassiano Dias de [75 anos]. [dez. 2005]. Entrevistador: Edson Silva. Pesqueira, Aldeia Cana Brava, Serra do Ororubá, PE, 13 dez. 2005.

Resumo: Neste texto buscamos evidenciar as diversas formas de trabalho exercido pelos indígenas Xukuru do Ororubá, atuais habitantes em um território que compreende os municípios de Pesqueira e Poção, no Semiárido pernambucano, região com pouca incidência de chuvas anuais, longas estiagens ou secas prolongadas. A partir de registros históricos e principalmente relatos das memórias orais indígenas, discutimos o trabalho próprio na agricultura, para os fazendeiros invasores das terras indígenas ou como operários na agroindústria em Pesqueira. E ainda, por falta de terras e em razão da seca, o trabalho na lavoura canavieira na Zona da Mata Sul pernambucana e Norte alagoana, ou nas plantaçóes de algodáo no Sertão paraibano. Bem como, após a conquista da demarcação do território em 2001, a experiência de cultivos agroecológicos, a recente e nova forma de trabalho na agricultura para a vida com dignidade, para afirmação da identidade indígena no Semiárido pernambucano.

Palavras-chave: Trabalho. Memórias. Indígenas Xukuru do Ororubá. Semiárido.

The indigenous people Xukuru of Ororubá and the ways of working: from farmers to workers and organic producers (Pesqueira and Poçáo/PE) 


\begin{abstract}
In this text we seek to highlight the various forms of work carried out by the Xukuru do Ororubá indigenous people, current inhabitants in a territory that comprises the municipalities of Pesqueira and Poção, in the Pernambuco semi-arid region, a region with little annual rainfall, long droughts or dry seasons. Based on historical records and mainly reports from indigenous oral memories, we discuss their own work in agriculture, for farmers invading indigenous lands or as workers in the agro-industry in Pesqueira. And, due to lack of land and due to drought, work in the sugarcane fields in the Zone of Mata Sul in Pernambuco and North Alagoas, or in the cotton plantations in the Paraíba hinterland. As well, as after the conquest of the demarcation of the territory in 2001, the experience of agroecological crops, the recent and new way of working in agriculture for life with dignity, for affirming the indigenous identity in the Pernambuco semi-arid region.
\end{abstract}

Keywords: Work. Memories. Indigenous people Xukuru of Ororubá. Semi-arid.

Recebido em 24/08/20

Aprovado em 21/10/20 